Volume and Issues Obtainable at Center for Sustainability Research and Consultancy
Journal of Business and Social Review in Emerging Economies
ISSN: 2519-089X \& ISSN (E): 2519-0326
Volume 7: Issue 4 December, 2021
¿SR
Journal homepage: www.publishing.globalcsrc.org/jbsee

\title{
Madaris in Pakistan: Religious and Social Challenges
}

*Surriya Shahab, Institute of Social and Cultural Studies, Bahauddin Zakariya University, Multan, Pakistan

Munir Ahmad, Department of Pakistan Studies, Bahauddin Zakariya University, Multan,

Pakistan

Muhammad Saleem Qazi, Department of Pakistan Studies, Bahauddin Zakariya University, Multan, Pakistan

Muhammad Asif Rasheed, Department of Pakistan Studies, Bahauddin Zakariya University, Multan, Pakistan

*Corresponding author's Email: suriishaque786@gmail.com

\begin{tabular}{l}
\hline ARTICLE DETAILS \\
\hline History \\
Revised format: Nov 2021 \\
Available Online: Dec 2021 \\
\hline Keywords \\
Madaris, Religious and \\
Social Challenges, Funding \\
and Agenda Setting \\
\hline
\end{tabular}

JEL Classification

N3, Z12 ABSTRACT

Purpose: The nature and extent of religious and social challenges posed by the madaris have been studied by scholars on a micro level, but there is a need of methodologically investigating of the problems on a macro and global levels by using a multidisciplinary and collaborative approach to readdress these issues. The purpose of this research paper is to find out the role of for causing militancy in Pakistan and to recommend measures/strategies for de-radicalization in Pakistan.

Design/Methodology/Approach: Agenda setting, priming and farming theories were used in this study. Qualitative content analysis method was used in this study to analyze the editorial policy of these three newspapers.

Findings: The results revealed that all these three newspapers gave significant coverage to the peace talks issue but Nation gave more coverage to the issue. Findings also revealed that Dawn and The News, most of the time showed neutral behavior but tilted towards unfavorable position regarding peace talks. Nation showed strongly unfavorable behavior regarding peace talks.

Implications/Originality/Value: So it is concluded that the government should take steps to take madaris in main stream education system in Pakistan. The funding should be checked and audited.

(C) 2021 The authors, under a Creative Commons AttributionNonCommercial 4.0

Recommended citation: Shahab, S., Ahmad, M., Qazi, M. S. and Rasheed, M. A. (2021). Madaris in Pakistan: Religious and Social Challenges. Journal of Business and Social Review in Emerging Economies, 7 (4), 927-934.

\section{Introduction}

It is alleged that Madaris Education is causing Religious radicalization, Extremism and 
aggressiveness in Pakistan, which is not only a menace to global peace and security, is also a significant cause of political uncertainty in Pakistan. It is an abysmal problematic in Pakistan that is pouring local, regional and worldwide instability (Fani, 2007). Now, for the first time, Muslims and non-Muslims are facing a common enemy in the form of globally engaged Islamist terrorism and during the present wave of militancy; Pakistan is coarsely affected by terrorist acts. The driving motives behind the cause of militancy are mostly religious, political, ideological, economic, and social (Ali, 2010). The emergence of different Islamic militant groups in Pakistan under the umbrella of the religious sectarian factions and their capability to forge alleged close ties to Madaris are posing a major security threat to global, regional and domestic peace (Kimball, 2005). The Islamic Republican of Pakistan is only Muslim country which appeared on the map of the world on an Islamic Ideology has a forceful militant Islamic lobby under the influence of religious parties. There are a smaller number of violent Sunni and Shia Islamist groups in Pakistan which are persuaded by the teaching of Madrasas education (Fani, 2007).

Islam is a religion of peace and tolerance that holds to the Supremacy of Allah (God) and the revelations of all Prophets and it has a central place in every aspect of life, especially politics. The philosophy and the teachings of Islam emphasize the Muslims that this life is to worship Allah and that we are placed on this earth in order to worship and obey the command of Him. "Did you think that we have created you in jest, and that you would not be brought back to US (for account)?'(Al- Quran, 23:115). Most Muslims are not fundamentalists, and most fundamentalists are not terrorists, but most present-day alleged terrorists are Muslims and proudly identify themselves as such (Lewis, 2004). In couple of decades, religion has played a considerable role and influences on politics in many regions of the world and has been a major factor in recent acts of terrorism, Pakistan particularly (Fani, 2007). The examples of religious extremists can be found in all religious traditions and no holds a monopoly on violence. All religious traditions can be used to justify acts of destruction and aggression (Juergensmeyer, 2005). The political resurgence of Islam in many countries from Morocco to the Philippines has accumulated with increasing speed (Jansen, 1979). The Islamist discourse has received a great deal of attention worldwide due to the collapse of the Soviet system and the ensuring of the New World Order (Abu-Rabi, 2003). Most Pakistanis are not extremists, and many are tolerant, both of differences within Islam and of non-Muslim believers (ECP, 2008). The election results of February, 2008 clearly verify this statement. In Feb. 2008 Elections, the alliances of Religious Parties, The Muttahida Majlis-i-Amal (MMA) got only 07 seats out of 342 in National Assembly(Fani, 2007). Madaris generally provide religious education, free accommodation and meals to the students (Ali, 2006), which, for those parents living below the poverty line and with large families to boot, is a great blessing and attraction. They feel that sending their sons to madaris is a much better economic proposition than to a public school. The state thus leaves with no other option for them expect to send their sons to madaris. Abandoning the children of the poor to the madrassah sector bears social costs not only in the form of exposure to abuse and diminished educational opportunities but also in increased intolerance and militancy.

The September 11, 2001 attacks on the symbols of the US financial power, the World Trade Centre in New York City, and military power, the Pentagon in Arlington County, Virginia, near Washington, D.C and the plane crash near the town of Shanks Ville in Somerset County, Pennsylvania have dramatically changed the political landscape of the world (Woollcott, 2002). These 9/11 terrorist attacks have brought Islamic militancy to the world in an unmatched way. These terrorist events were construed as proof that Muslims militants would smack any nation to quench their thirst for violence and attacks changed the ontology of Islamic terrorism. The act of Islamic militants (who are in minority) in 9/11 attacks has been a catalyst to further aggravate the misconceptions about Islam and is being projected as the principal source of international terrorism (Fani, 2007). Conflict and tension between Islam and the West has been prevalent through history. Some western scholars have mixed jihad with terrorism and are using Islamic 
terrorism (Islamist terrorism) or Jihadist terrorism (Levonian, 1940). Muslims in many countries were seen as subversive agitators, Jihadists, militants, and involved in vast pan-Islamic plots. More important, distorted and inflammatory linkages between Islam and terrorism can convince Muslims that the West is their enemy (Smith, 2007). Islam is repainted in the global consciousness as a religion of violence. A new paradigm began to emerge in the non-Muslim world that Islamic militancy due Madaris Education in the Middle East, Pakistan, Afghanistan, Chechnya and some other places derives its unrelenting impulse for violence from the faith itself. The Muslims were seen by the larger public in the USA as homogeneously complicit in these brutal acts and the Pakistani madaris got attention of the policy makers of the world in this regard(Fair, 2009).

In Pakistan, the issues like the failure of parliamentary democracy, the weakening of civil society, the interventions of military and so called Afghan Jihad i.e. the outbreak of war in Afghanistan and spreading Madaris after 1979 have prompted the growth of social protests in the form of Islamic militancy and political Islam. The army dictators portrayed themselves as the guardian and custodian of democracy in Pakistan but in fact are obstacles to it (Shafqat, 1997). The Pakistani military saw themselves as the essential core, the nucleus of the Pakistani state. The civilian politicians were considered as anti-national, corrupt and disloyal and therefore needed to be supervised. Despite Benazir Bhutto's pronouncements regarding Pakistan's role as a moderate Islamic state, the military continued to regard the militant Islamic parties and Madaris as a tool for furthering Pakistani interests in Afghanistan and Kashmir (Gerges, 1999). The armed forces grip on the political process, especially its relationship with the Jihadi groups and Madaris between 1996 and 2001, was such that a former Prime Minister of Pakistan acknowledged the Inter-Services Intelligence (ISI) to be a state with in state. It has now been established by several scholarly and journalistic works that the Pakistan military establishment directly assisted the Taliban's rise (Davis, 1998). This has contributed to the growth of political Islam, Islamic militancy and has given political protests a religious outlet (Rashid, 2000).

After the Soviet invasion, the madaris underwent a significant logistical and conceptual transformation (Fani, 2007). Although the Soviet Union withdrew from Afghanistan, the madaris continued to function within the framework of minimal education and maximal spirit of jihad. The religious students educated in Pakistani Deobandi madrassas formed the core of the Taliban (Hussain, 2005). It is common perception in Pakistani intellectuals that the decisive battle of the Cold War was fought and won for the West in Afghanistan by the Afghan Mujahideen' or Holy Warriors with the aid of the US resources mediated through Pakistan(Fani, 2007). They were trained, indoctrinated, armed and given financial assistance by the West and the more affluent 'moderate' Islamic countries, notably Saudi Arabia. Thousands of volunteers from Muslim countries, particularly the Arab world, were flown to training camps in Pakistan and sent into Afghanistan to fight the Soviet occupation forces. They were acclaimed as the 'Mujahideen' or Holy Warriors and were lionized as the heroes of the liberation struggle. After 9/11 attacks, the role of Pakistani madaris in shaping radical views among the masses and specially the students studying therein has been a prominent feature of the debates on terrorism and has been a matter of serious concern for many analysts and policy makers in the USA and West(International Crisis Group, 2004). The US and its allies have launched a campaign to ban the teaching of jihad in the madaris. The Southern Punjab madaris, in particular, are perceived by the western media as a crucial medium for promoting religious extremism, Jihadi culture and sectarianism (Rana, 2010). The religious and ideological training given in madaris plays a crucial role in expanding the network of religious extremists in Pakistan. The number of madaris with ties to Islamist radicals has increased. The unregulated madaris and mosques are creating religious radicalization and militancy in Pakistan and thus are posing serious threats to its social and political stability (Fani, 2007). The affiliation of the madaris with political, sectarian and militant organizations is a major cause of this very concern. Such affiliations of the madaris may drive their administration and 
students toward an increased political role. Many analysts view that although not all madaris have direct links with terrorism (Bergen \& Pandey, 2006) but approximately 10-15 percent does (Singer, 2005). Much of information about Madaris is anecdotal (Fair, 2009). The study was conducted to examine alleged 79 terrorists who were responsible for five of the worst antiWestern terrorist attacks and even though none of the attackers studied in madaris in Pakistan or elsewhere(Fair, 2009) and further noted that masterminds of the attacks all had university degrees(Bergen \& Pandey, 2006). Madaris and mosques have multiplied in Pakistan at a rapid pace since the mid-1980s, the heyday of the anti- Soviet Jihad in Afghanistan. There are approximately 3800 madaris and 25000 mosques of five major sects in 51 Tehsils of 14 Districts of the Southern Punjab.

\section{Statement of the Problem/Hypothesis}

Following the terrorist attacks of September 11, 2001, the proliferation of Pakistani madaris has been noted with particular consternation and they are alleged to be incubators of militants in Pakistan and are thought to be responsible for creating communities of support for militancy in the region.

\section{Objectives and Aims of Research}

The following objectives and aims were set to complete this research work:

1- The nature and extent of religious and social challenges posed by the madaris have been studied by Pakistani and Western scholars on a micro/ local level, but there is a need of methodologically investigating of the problems/issues on a macro and regional levels by using a multi-disciplinary and collaborative approach to readdress these issues. The comprehensive and objective assessments of madaris education in Pakistan and its impacts on society were carried out by using the same approaches and techniques.

2- The countrywide figures about madaris and mosques are disputed in Pakistan and no one agrees to these because of the non-reliability of official estimates. Thus, there is a need for collection of reliable statistical data. This study was, therefore, aimed to conduct a thorough and transparent survey of the madaris and mosques for collecting exact figure, reliable information and statistical data of students enrollment in different madaris of the Southern Punjab, their family background and affiliations of the madaris and mosques with political, sectarian and militant organizations so as to make a comprehensive and objective assessment of madaris education, particularly with reference to the collection of data of different available books in the libraries of the madaris and the impact of their contents on the society, and to trace evidences as regards linkages of madaris with different militant organizations and Jihadi groups working in Pakistan, Afghanistan etc.

3- To investigate the local and foreign funding sources of the madaris as well as the pattern of their expenditures and utilization on different activities related to the madaris and mosques and to recommend measures/strategies for de-radicalization.

\section{Research Methodology}

Research is the product of knowledge about a given subject matter and people who produce and control such knowledge increase their power to deal with the particular issues involved (Barnard, 2000). The methodology is the order line of any research work, which deals with the technique of investigation of phenomena and a process of research, essentially empirical in data collection and data analysis (Pandey, 2001). The present study is related to the issues of religious education and alleged links of madaris to religious extremism. It focuses the role of Southern Punjab madaris and mosques played in emerging religious radicalization and militancy in Pakistan, and strategies adopted for countering their effects of violence with a cursory glance at its historic perspective 
and evolution in Pakistan and the other parts of the world. This research was done on the basis of public material already collected by various government and semi-government/autonomous bodies, field survey, data collection, the individual's research reports, findings of think tanks, articles, newspapers, magazines, books etc. Further, this research was based both on a contextual and a textual approach to Madaris Education and challenges in Pakistan. The longstanding literature on Islamic educational institutions was also used for completing this study. The methodology of this research was theoretical as well as applied. A historical inquiry in such a situation can discern patterns in the evolution of political events and determine whether these patterns have a recurring theme in history. In the context of historical perspective and analysis, the renowned scholar, Hedley Bull has strongly advocated and recommended a research agenda for the study of world politics based on historical methodology as opposed to a total reliance on a 'scientific' approach derived from behavioral methods (Bull, 1972). This method was used by conducting the present study. The use of history enables the scholars to understand the particular characteristics of a state (Baruch, 1952, Banfield, 1961). By conducting this particular research on Madaris Education in Pakistan, the same role and behaviour of the state actors has been examined because the historical perspectives of madaris education are playing major role in present wave of militancy in Pakistan. This research proposed to develop a model of transnational networking of civil society across the Muslim world and beyond, with a view to reshape the intellectual and professional currents of opinions along the global agenda of peace and harmony. A model was built by connecting themes in a network or pattern (Bush \& Mosteller, 1955) and can be used to summarize data. The field survey and the documentary primary and secondary sources were used for getting information and collecting data to complete this research and reach the final findings and recommendations.

\section{Field Survey}

Field survey is one of many available research methods and a wide variety of data-collecting techniques, including various kinds of interviews, questionnaires, census data, tape recordings, projective techniques and content analysis of essays and stories is used in empirical research (Mills, 1951). Fink describes surveys as ways of producing information to describe, compare and predict attitudes, opinions, values and behaviour based on what people say or see and what is contained in records about them and their activities (Fink, 1995). Ackroyd and Hughes characterize survey into four distinct categories: factual; attitudinal; social psychological and explanatory (Ackroyed \& Hughes, 1993). Gans' study of Levittown was based on questionnaires, interviews and participant observation (Gans, 1967). Karsh in his study of a strike used structured interviews that were subjected to content analysis and also files correspondence, photographs, newspapers clipping, songs, and court transcripts, outlines of speeches, notes and personal memos (Karsh, 1958). In this study, a transparent field survey was used for collecting the real data of the selected madaris and mosques in the Southern Punjab, which comprised the common questionnaires, in-depth individuals interviews, and the interviews of stakeholders, the selected madaris students and teachers, leaders of the religious -political parties, ethno political groups, militant groups, the officials of the organizations, including the federal and provincial governments, NGOs and the key players involved in the policy and decision making process in Pakistan. We developed inventory of infrastructure, timetabling and other activities of the madaris. The teaching style of the faculty and the special seminars, if conducted by them on the current issues of interest, were also documented to analyze the working of the madaris. Selfadministered and semi- structured questionnaires were used as means of ensuring some consistency in the data gathered during the research. Self-administered questionnaires facilitate confidentially and anonymity. The usages of interviews in various research projects are now wide-spread and widely accepted. These offer the opportunity to sit and listen to people's concerns and opinions at a level inaccessible to a questionnaire (Stroh, 2000). Interviews are used extensively by sociologists that Benny and Hughes have referred to Modern Sociology as "the Science of the Interview (Benney \& Hughes, 1956). According to Dawn Burton, "Face-to-face 
interviews are far better at eliciting data to open-ended questions. Self-administered questionnaires are better at generating information from highly structured questions where respondents are required to tick an appropriate box (Burton, 2000). Face-to-face interviews and Self-administered questionnaires were also used during this study. The collected information and data was analyzed from the viewpoint of Ulema of various sects, different intelligence agencies, the government/police investigation reports. A cross comparison of all these helped us to understand the ground realities of madaris education and the typical mindset of their students and teachers. Attention was focused on the strategies and sharing of the best practices for deradicalization.

\section{Documentary Sources}

Documentary sources consist of primary and secondary sources in form of published and nonpublished documents, official reports and the reports of the agencies, secrets reports, manuscripts, Intelligence Bureau (IB) reports, Inter-Services Intelligence (ISI) reports, Special branch reports, Military Intelligence (MI) reports, Police reports, diaries, letters, newspapers, research journals and books. First hand data in form of un-published official records, files, letters, police investigate reports and other firsthand data and reports which are available in different sections of the Ministry of Interior Affairs, Ministry of Foreign Affairs, Ministry of Religious Affairs, Cabinet Division, Ministry of Law and Parliamentary Affairs, Home Departments, Human Rights Commission, and Police Departments in Pakistan were primary sources which were used for this research. The books, newspapers, periodic and journals are major secondary sources and these were also used. This research was Qualitative and Quantitative. On the basis of qualitative methodology, the Ground Theory, assumptions and predictions and historical approaches were applied.

\section{Conclusion}

This research article gives a local, regional and worldwide viewpoint on the link amongst religion, politics, conflict and identity. By means of a extensive range of cases from Pakistan, it observes the multifaceted means in which religious values, beliefs and norms rouse and affect political developments and behaviour of the society; the social conditions, which give rise to religious movements as well as how much movements are promoted and sustained over time; the relations between religious leaders and followers; and the relations between social mobilization and the pursuit of particularistic objectives. So, findings and recommendations are being made on the basis of the unprecedented field work and the judicious use of the existing literature. This study plays a unique role to devise workable strategies addressing the most intractable conflicts with innovative public policy solutions for Pakistan and some other countries. These findings also provide a base and guideline for the Government of Pakistan to introduce proper reforms in madaris education. The problems stated in the study, readdresses through making efforts for inter-sectarian and inter- religion dialogue. So, the present research is a true benchmark study, which establishes the standard and clear guideline for the future researchers to conduct research work on the core issues and problems of madaris education and religious establishment in Pakistan.

Some madaris and mosques are fuelling the present wave of religious radicalization and militancy in Pakistan and the present study not only traced out the root causes of violence but also proposed concrete measures and steps to be taken by the Government of Pakistan as well as the five registered Madaris Boards to counter terrorist effects and radicalization. So, this research will be an intrinsic value for foreign analysts and policy makers. This study also proves to be an invaluable guide for policy makers, both in Pakistan and in the communities of the states that wish to develop a truly modern and effective educational system for madaris. So, a set of reforms-related issues and suggestions from the viewpoints of the government, the madaris' administrators and educators, and the Islamic scholars are presented. This study has also an 
academic significance, as it will be helpful in updating the available literature on this field of study. This will also useful for developing the curriculum of madaris education and for education in colleges and universities.

\section{References}

Abu-Rabi, I.M. (Ed.). (2003). Islam at the Cross roads: On the Life and Thought of Bediuzzaman Said Nursi. State University of New York Press.

Ackroyd, S. and Hughes, J. A. (1993). Data Collection in Context. Longman Publisher.

Ali, F. (2010). The Rise of Militant Islam in Pakistan: Its Impacts on Society [Unpublished

M. Phil Thesis]. Bahauddin Zakariya University, Multan.

Ali, S.H. (2006). Islam and Education conflict and conformity in Pakistan's Madrassahs. In

Ashgate Publishing limited.

Banfield, E. (1961). Political Influence. Free Press.

Baruch, D. W. (1952). One Little Boy. Julian Press.

Benney, M. and E. C. Hughes. (1956). Of sociology and the interview. American Journal of Sociology, 62, 137-42.

Bergen, P. \& Pandey, S. (2006). The Madrassa Scapegoat. The Washington Quarterly, 29(2), 117-125.

Bernard, W. T. (2000). Participatory Research as Emancipatory Method: Challenges and Opportunities. In Dawn Burton (Ed.), Research Training for Social Scientists. Sage Publications.

Bull, H. (1972). International Relations as an Academic Pursuit. Australian Outlook, 26, 251262.

Burton, D. (2000). Data Collection Issues in Survey Research. In Dawn Burton (Ed.), Research Training for Social Scientists. Sage Publications.

Bush, R. R. and Mosteller, F. (1955). Stochastic Models for Learning. John Wiley and Sons.

C. Baxter \& C. Kennedy (Eds.), Pakistan: 2005(pp.13-43). Oxford University Press.

Davis, A. (1998). How the Taliban Became a Military Force. In W. Maley(Ed.), Fundamentalism Reborn: Afghanistan and the Taliban. Hurst Publisher.

Fair, C.C. (2009). The Madrassah Challenge: Militancy and Religious Education in Pakistan. Vanguard Publisher.

Fani, M. I. (2007). Islamic Militancy, Religious Ethnicity; Causes and Roots: Its Impacts on Society, A Case Study Of Pakistan [Unpublished Post-Doctoral Research Work]. University of Pennsylvania, Philadelphia.

Fink, A. (1995). How to Design Surveys. Sage Publications.

Gans, H. (1967). The Levittowners. Pantheon Publisher.

Gerges, F. A. (1999). America and Political Islam: Clashes of Culture or Clash of Interests. Cambridge University.

http://www.ecp.gov.pk/NAPosition.pdf

International Crisis Group. (2004). Unfulfilled Promises: Pakistan's Failure to Tackle Extremism. Asia Report No 73.

Jansen, G.H. (1979). Militant Islam. Pan Books Ltd.

Juergensmeyer, M. (2005, March 8-11). Addressing the Causes of Terrorism: Religion.The International Summit on Democracy, Terrorism and Security 2005. Madrid, Spain.

Karsh, B. (1958). Diary of a Strike. University of Illinois Press.

Kimball, Charles A. (2005). Examining Islamic Militancy. North Carolina: USA.

Levonian, L. (1940). Studies in the Relationship between Islam and Christianity. Allen and Unwind Publishers.

Lewis, B. (2004). The Crises of Islam: Holy War and Unholy Terror. Orion House Publisher.

Mills, C. W. (1951). White Collar. Oxford University Press.

P.W Singer,P.W. Pakistan's Madrassahs Ensuring a System of Education, not Jihad. Brookings Institute. Report No. 41. 
Pandey, S.R. (2001). Methodology in Social Science Research. Nepal Centre for Contemporary Studies.

Quran 23: 115, translated by A. Y. Ali, 2002.

Rana, M. A. (2010). Mapping the Madrasa Mindset: Political Attitudes of Pakistani Madaris. Conflict and Peace Studies, 2(1).

Rashid, A. (2000). Taliban: Islam Oil and the Great Game in Central Asia. IB. Tauris Publisher.

Rizwan Hussain, R. (2005). Pakistan and the Emergence of Islamic Militancy in Afghanistan.

Sage Publications.

Shafqat, S. (1997). Civil-military relations in Pakistan. From Zulfikar Ali Bhutto to Benazir Bhutto. Boulder Publishing Company.

Smith. A. (2007). Words Make Worlds Terrorism and Language. FBI Law Enforcement Bulletin, $76(12)$.

Stroh, M. (2000). Qualitative Interviewing. In Dawn Burton(Ed.), Research Training for Social Scientists.

Vanguard Books.

Woollcott, M. (2002, May 24). Kashmir and Terrorism are not the problem, it's the Bomb. The Guardian, London. 